\title{
Physiological Markers for Assessing Germinability of Lycopersicon esculentum Seeds Primed by Environment-Friendly Methods
}

\author{
Bogumila Badek ${ }^{1}$, Zdzislawa Romanowska-Duda ${ }^{2 *}$, \\ Mieczyslaw Grzesik ${ }^{1}$, Anita Kuras ${ }^{1}$ \\ ${ }^{1}$ Research Institute of Horticulture, \\ Konstytucji 3 Maja 1/ 3, 96-100 Skierniewice, Poland \\ ${ }^{2}$ Department of Ecophysiology and Plant Development, University of Łódź \\ Banacha 12/16, 90-232 Łódź, Poland
}

Received: 30 March 2016

Accepted: 5 May 2016

\begin{abstract}
Correlations between the sowing value of primed tomato seeds (mean germination time - MGT, germination uniformity $-\mathrm{T}_{75-25}$ ) and selected physiological events (total activity of dehydrogenases - TAD, activity of catalase - AC, activity of the cell cycle - ACC, and leakage of electrolytes - LE) were analyzed in order to find useful physiological markers of seed quality. To accomplish this purpose, we analyzed the effects of different environment-friendly priming methods, the levels of seed moisture content (MC), and incubation times during priming on germination properties $\left(\mathrm{MGT}, \mathrm{T}_{75-25}\right.$ ) in relation to TAD, $\mathrm{AC}, \mathrm{ACC}$, and LE. In addition, we evaluated the effects of used seed conditioning methods on the growth and development of plants obtained from these seeds.

The results showed positive effects of seed conditioning on the growth and development of plants obtained from these seeds, and that MGT and $\mathrm{T}_{75-25}$ were significantly correlated with TAD, AC, ACC, and LE from the seeds. The correlations between MGT and the physiological parameters were the strongest $\left(r^{2}=77.0-97.2 \%\right)$. Somewhat lower values of the determination coefficient $\left(r^{2}=62.8-92.7 \%\right)$ were noted between $\mathrm{T}_{75-25}$ and the physiological events. Therefore, the investigated physiological parameters of seed quality can be used as markers of germinability and sowing value reached by primed tomato seeds.
\end{abstract}

Keywords: catalase, cell cycle, dehydrogenases, leakage of electrolytes, seed priming

\section{Introduction}

Germinability of seeds is established during their development, maturation, and pre-sowing processing.

*e-mail: romano@biol.uni.lodz.pl
Evaluating the germination capacity and identifying high-performance seeds are important incentives toward successful crop production. A significant problem during their quality evaluation is the lack of a single, rapid, and universally used marker for assessing the physiological potential of seeds of a given species. A reliable physiological marker would be a faster alternative than 
assessing germination percentage and vigor in laboratory and field tests. They are also needed for monitoring the physiological events in seeds during pre-sowing conditioning. For this reason, studies on the identification of factors that indicate the quality and sowing value of seeds have been considered important in the present research. In recent years, some physiological parameters such as accumulation of $\beta$-tubulin [1-2], cell-cycle activity [3], changes in the amount, replication of DNA [4], activity of some enzymes, and cytomembrane permeability [5-6] have been used to determine physiological events in pretreated and germinating embryos. However, the published data did not provide information that would indicate a correlation between the changing parameters of seed germinability and the selected physiological activities, which could be proposed as useful markers of seedsowing quality. This information is important in practice, among other things, to evaluate the results of seed priming, which is used for improving their germination, vigor, and seedling emergence - especially in unfavorable environmental conditions [7-9].

Priming causes several metabolic processes during controlled imbibition and incubation of seeds in order to initiate metabolic pre-germination events without allowing penetration of the seed coat by the embryonic root $[8,10]$. Early initiation of physiological activities and mobilization of metabolites might be a reason for faster germination. However, interference in the course of metabolic processes, their optimization, and prevention of negative effects requires precise physiological monitoring of priming conditions and the application of proper markers that would indicate the events occurring during and after this treatment [11]. Indication of the correlation between the chosen physiological processes and seed germination parameters can be helpful in predicting the methods for early diagnosis of seed quality.

The aim of the present study was to find physiological markers that would help to evaluate the effects of eco-presowing priming on tomato seed quality. To achieve this aim, we analyzed the correlation between the tomato seed sowing value (mean germination time - MGT) and germination uniformity (time between 25 and $75 \%$ of germinated seeds $-\mathrm{T}_{75}{ }_{25}$ ) on the one hand, and selected physiological events (total activity of dehydrogenases - TAD, activity of catalase - AC, activity of the cell cycle - ACC, and leakage of electrolytes - LE), on the other hand. To investigate the usefulness of the studied markers we evaluated the influence of the environmentally friendly methods of seed hydration, moisture content, and the time of incubation during priming on the activity of the chosen physiological processes, in comparison with germination parameters.

\section{Material and Methods}

The experiments were conducted with seeds of the Janosik tomato (Lycopersicon esculentum Mill.) obtained from the PNOS Ożarów seed-distributing company in
Mazowiecki, Poland. The seeds (germinating in 90.7\%) were stored in standard storage conditions and then were divided into several batches, one of which served as control, while the others were subjected to different methods of conditioning. Hydration of tomato seeds up to $30.0,35.0$, and $40.0 \% \mathrm{MC}$ and their incubation for 1,10 , and 12 days were chosen for the experiments on the basis of earlier research, as the most promising treatments [12-13]. Calflo, used for seed matriconditioning was obtained from Celite Corporation, Lompoc, CA 93438, USA.

\section{Seed Conditioning}

Three environmentally friendly methods of seed conditioning were used in the experiments:

1. Soaking in an excessive amount of water (M1): seeds were soaked in aerated, distilled water at a ratio of seeds to water of $1: 3 \mathrm{v} / \mathrm{v}$, for 60,240 , and $720 \mathrm{~min}$. at $20^{\circ} \mathrm{C}$, to obtain a seed moisture contents of $30.0,35.0$, and $40.0 \%$, respectively. After hydration, the seeds were surface-dried between sheets of filter paper for five seconds, and subsequently incubated for one, 10, and 12 days in airtight glass bottles, aerated daily, at $20^{\circ} \mathrm{C}$.

2. Soaking in a limited amount of water (M2): seeds were soaked in 320, 480, and $560 \mathrm{ml}$ of water per kilogram of seeds to obtain their moisture contents of 30.0 , 35.0 , and $40.0 \%$, respectively, and were subsequently incubated for one, 10 , and 12 days in airtight glass bottles, aerated daily, at $20^{\circ} \mathrm{C}$.

3. Matriconditioning (M3): seeds were matriconditioned by mixing them with Calflo and water, and then incubating for one, 10 , and 12 days at $20^{\circ} \mathrm{C}$ in airtight glass bottles. The ratio of seeds to Calflo was constant $(1.0: 0.4 \mathrm{w} / \mathrm{w})$, whereas the ratio of seeds to water varied: $1.0: 0.6,1.0: 0.8$, and $1.0: 1.4 \mathrm{w} / \mathrm{w}$ to obtain moisture contents of 30.0, 35.0, and 40.0\%, respectively. The matriconditioned seeds were aerated every day for a few seconds. After the incubation, the seeds were rinsed for five seconds with distilled water to remove Calflo residues from the seed surface.

After conditioning, all seeds were dried for two days on filter paper at $20^{\circ} \mathrm{C}$ and $40.0 \%$ air relative humidity (RH). Then they were subjected to evaluations of moisture content (MC), mean time of germination (MGT), uniformity of germination $\left(\mathrm{T}_{75-25}\right)$, and physiological activity (total activity of dehydrogenases (TAD), activity of catalase (AC), leakage of electrolytes (LE), and activity of the cell cycle (ACC)).

\section{Seed Moisture Content}

The moisture content (MC) of seeds was determined in three replications according to the commonly applied ISTA procedure [14]. Seed samples were weighed, dried for $1 \mathrm{~h}$ at $130^{\circ} \mathrm{C}$, and reweighed. Seed moisture content results were calculated with these data and expressed on a fresh weight basis. 


\section{Seed Germination Properties}

Seed germination properties were evaluated at $15^{\circ} \mathrm{C}$. Three replicates of 50 seeds each were sown in $9.0-\mathrm{cm}$ diameter Petri-dishes on cotton wool moistened with 6.0 $\mathrm{ml}$ of distilled water. Germination was scored on a daily basis for 20 days. Each seed was counted as having germinated when its radical protruded through the seed coat and was removed from the Petri-dishes every day. MGT and $\mathrm{T}_{75-25}$ were determined by counting the germinated seeds daily and performing calculations using the Seed Calculator Version 3.0 computer program developed by Plant Research International B.V. (Wageningen, the Netherlands).

\section{Growth and Development of Plants}

We evaluated the growth and development of plants on the plants derived from the seeds moistened using three methods (M1, M2, M3) up to $35 \% \mathrm{MC}$ and incubated for 10 days (following the procedures described in "Seed conditioning"). The seedlings were grown for 30 days in a mixture of sand and sphagnum peat $(1: 1=\mathrm{v}: \mathrm{v})$, at $25-28^{\circ} \mathrm{C}$, and an eight-hour dark/16-hour light cycle (SON-T AGRO $400 \mathrm{~W}, 100 \mu \mathrm{molm}^{-2} \mathrm{x} \mathrm{s}^{-1}$ ). Then they were transferred to $20^{\circ} \mathrm{C}$. During the growing season we analyzed the length of the main shoot $[\mathrm{cm}]$ and the number of inflorescences. Results were assessed on the basis of the 20 replicates (one plant was counted as one replicate).

\section{Total Activity of Dehydrogenases}

The procedure described in [15] was used to assess TAD in seeds. The amount of formazan ( $\left.\mathrm{mg} \mathrm{x} \mathrm{g} \mathrm{seeds}^{-1}\right)$ was determined by comparing the levels of absorption by the tested extract and calibration solution. Absorption by the extract was measured at $480 \mathrm{~nm}$ (SHIMADZU UVmini-1240 spectrophotometer). For each treatment three replicates were used ( $0.1 \mathrm{~g}$ of seeds per extract).

\section{Activity of Catalase}

The activity of catalase (AC) was determined spectrophotometrically, as previously described by [16], following $\mathrm{H}_{2} \mathrm{O}_{2}$ consumption at $240 \mathrm{~nm}$. The UVmini-1240 spectrophotometer (SHIMADZU) and software for measuring kinetics (Kinetics Program Pack for UVmini-1240) were used. The testing was conducted in three replicates for each treatment using $0.5 \mathrm{~g}$ of seeds per extract.

\section{Leakage of Electrolytes}

The leakage of electrolytes (LE) was measured according to [15], with our own modification. The electrolyte leakage test was performed by soaking 30 seeds (uniform in size and with no visual damage) in $3 \mathrm{ml}$ of deionized water at $20^{\circ} \mathrm{C}$ for two and four hours, followed by measurements of conductivity of the solution using a
CC-551-Elmetron apparatus. Subsequently, the samples were boiled at $100^{\circ} \mathrm{C}$ for $12 \mathrm{~min}$. to enable measurements of the total leakage of electrolytes (LE) from seeds. The results were presented as a percentage of electrolytes obtained from seeds soaked for two and four hours in the total leakage of electrolytes, measured after boiling. The experiment was conducted in three replicates (30 seeds per replicate).

\section{Activity of the Cell Cycle}

We evaluated cell cycle activity using tomato seeds that had been soaked in water up to $30.0,35.0$, and $40.0 \%$ $\mathrm{MC}$ and incubated for one, 10, and 12 days. A sample for cytometric analysis was prepared according to the method described in [17]. The evaluation was conducted using a flow cytometer (Partec CCA, Münster, Germany), with the application of the logarithmic scale. Based on the results obtained, we calculated the percentage share of nuclei characteristics of different DNA content (4C). The experiment was conducted in three replicates (five radicles per extract).

\section{Statistical Analyses}

The experiments were conducted in a randomized complete design with three replicates. All data were subjected to analysis of variance and the significance of means was determined with Duncan's test at $\mathrm{P}<0.05$. Coefficients of determination ( $\mathrm{r}^{2}$ values) were used to evaluate the relationships between the tomato seed sowing value (MGT, $\mathrm{T}_{75-25}$ ) and the selected physiological events (TAD, AC, ACC, EC). A linear regression model was used for the analysis. STATISTICA version 10 program was used to perform all statistical analyses.

\section{Results and Discussion}

The vigor of seeds can be improved by means of various treatments referred to as 'seed priming.' During priming the seeds are subjected to controlled hydration in order to induce the transient activation of pre-germinative metabolism that includes, among other things, antioxidant functions and DNA repair processes [18]. Early repair mechanisms and activation of pre-germination physiological processes are recognized as the key physiological events underlying the beneficial effects of seed priming. The activity of catalase, dehydrogenases, and the cell cycle - or leakage of electrolytes - have been reported as useful events for indicating embryo physiological activity, which are associated with the development and germinability of seeds $[3,12,13,16,19]$. However, the previously reported data did not indicate correlations between the mentioned parameters. Our study aimed at investigating the possible relationships between MGT and $\mathrm{T}_{75-25}$ of primed tomato seeds and the activity of selected physiological processes taking place during their germination. The analyses of regression showed significantly $(p<0.001)$ 
positive correlations between $\mathrm{LE}$ and MGT or $\mathrm{T}_{75-25}$. In contrast, there were negative correlations between MGT or $\mathrm{T}_{75-25}$ and AC, and TAD and ACC (Figs 1-6). The high, positive, or negative correlation between the occurring physiological activities and MGT or $\mathrm{T}_{75-25}$ indicates the possibility of using these events as markers of seed biological quality.
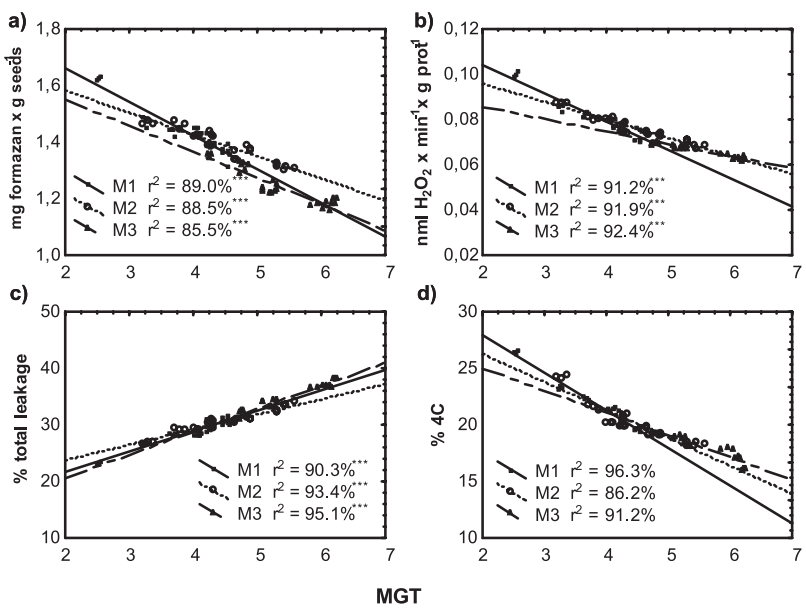

Fig. 1. Linear regressions between mean germination time (MGT) and physiological activities - a) total activity of dehydrogenases - TAD, b) activity of catalase - AC, c) leakage of electrolytes - LE, and d) activity of cell cycle ACC - of tomato seeds imbibed up to $30.0,35.0,40.0 \%$ and then incubated for one, 10, and 12 days in relation to applied methods of conditioning: soaking in an excessive amount of water (M1), soaking in a limited amount of water (M2), or matriconditioning (M3); ${ }^{* * *}$ - significance of correlation at $\mathrm{p}<0.0001$ according to student statistic.
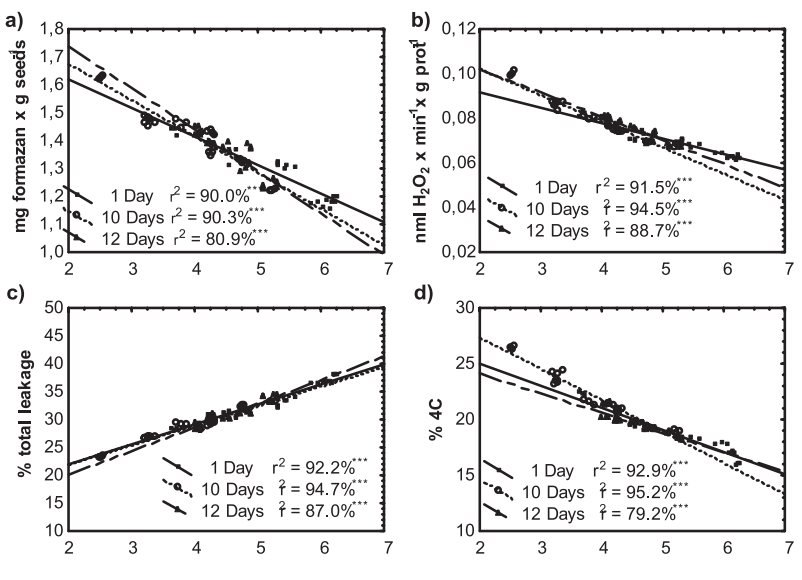

MGT

Fig. 2. Linear regressions between mean germination time (MGT) and physiological activities - a) total activity of dehydrogenases - TAD, b) activity of catalase - AC, c) leakage of electrolytes - LE, and d) activity of cell cycle - ACC - of tomato seeds imbibed up to $30.0,35.0,40.0 \%$ by soaking in an excessive amount of water (M1), soaking in a limited amount of water (M2), or matriconditioning (M3) in relation to applied time of incubation (one, 10 , and 12 days at $20^{\circ} \mathrm{C}$ ); ${ }^{* * *}$ - significance of correlation at $\mathrm{p}<0.0001$ according to student statistic.
The improvement in germination of primed tomato seeds was associated with a range of biochemical changes that are required to initiate the germination processes and affect hydration, enzyme activation, breaking of dormancy, storage material hydrolysis, or degradation of inhibitors. The analyses of variance showed positive
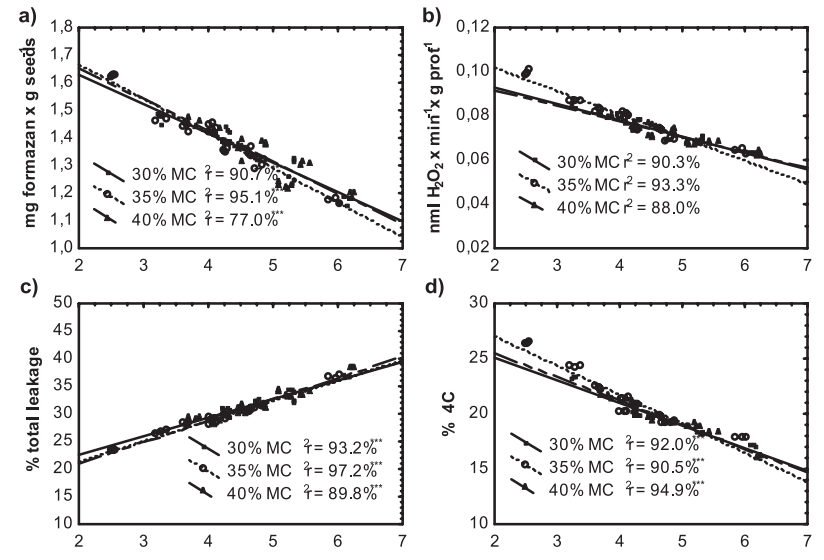

MGT

Fig. 3. Linear regressions between mean germination time (MGT) and physiological activities - a) total activity of dehydrogenases - TAD, b) activity of catalase - AC, c) leakage of electrolytes - LE, and d) activity of cell cycle - ACC - of tomato seeds imbibed by soaking in an excessive amount of water (M1), soaking in a limited amount of water (M2), or matriconditioning (M3), and then incubating for one, 10, and 12 days in relation to applied moisture content (MC) (30.0, 35.0 , and $40.0 \%) ;{ }^{* * *}$ - significance of correlation at $\mathrm{p}<0.0001$ according to student statistic.
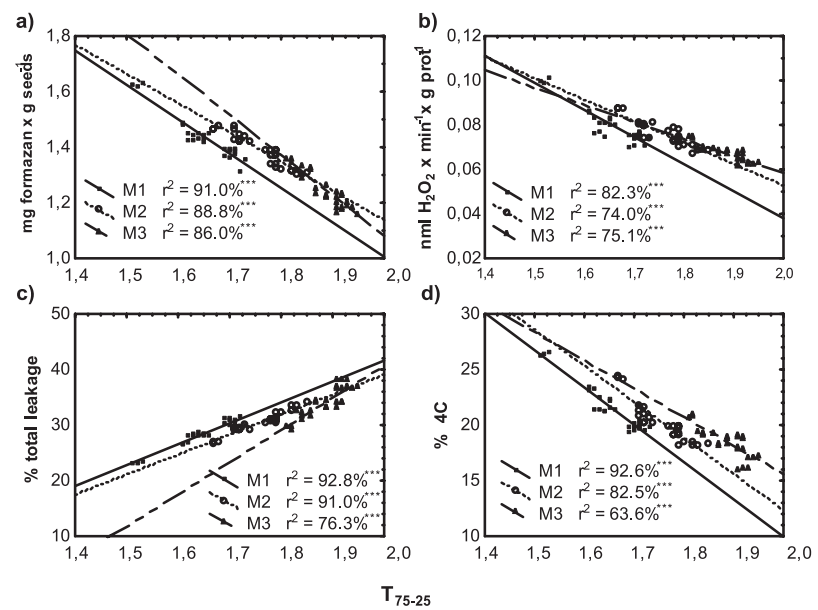

Fig. 4. Linear regressions between mean germination time (MGT) and physiological activities - a) total activity of dehydrogenases - TAD, b) activity of catalase - AC, c) leakage of electrolytes - LE, and d) activity of cell cycle ACC - of tomato seeds imbibed up to $30.0,35.0,40.0 \%$ and then incubating for one, 10 , and 12 days in relation to applied methods of conditioning (soaking in an excessive amount of water (M1), soaking in a limited amount of water (M2), or by matriconditioning (M3); ${ }^{* * *}$ - significance of correlation at $\mathrm{p}<0.0001$ according to student statistic. 
effects of environment-friendly conditioning on the germination parameters of tomato seeds. Each method of seed conditioning significantly shortened MGT and $\mathrm{T}_{75-}$ ${ }_{25}$ in degrees depending on the treatment (Table 1). The MGT was reduced from 6.52 days (control) down to 2.53 days (M1), 3.29 days (M2) and to 4.27 days (M3). The values of the $\mathrm{T}_{75-25}$ parameter for these seeds were reduced
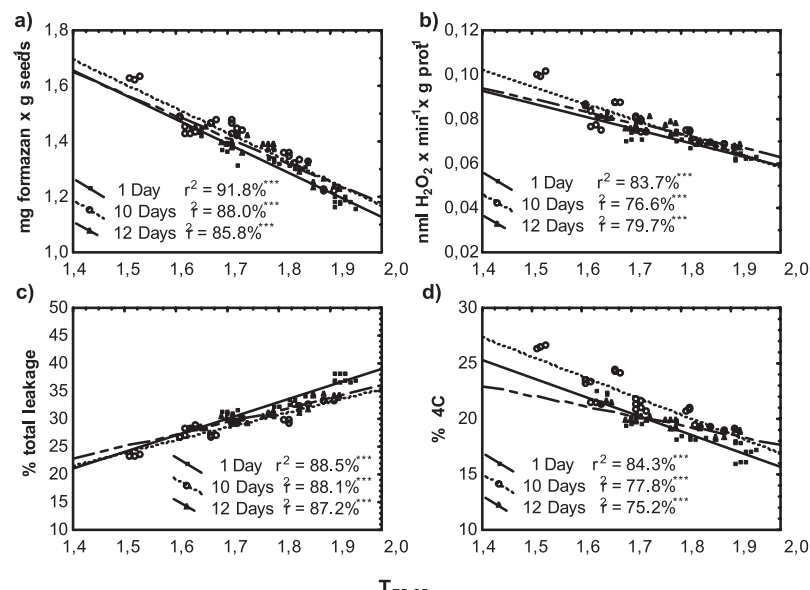

$\mathrm{T}_{75-25}$

Fig. 5. Linear regressions between mean germination time (MGT) and physiological activities - a) total activity of dehydrogenases - TAD, b) activity of catalase - AC, c) leakage of electrolytes - LE, and (D) activity of cell cycle - ACC - of tomato seeds imbibed up to $30.0,35.0,40.0 \%$ by soaking in an excessive amount of water (M1), soaking in a limited amount of water (M2), or matriconditioning (M3) in relation to applied time of incubation (one, 10 , and 12 days at $20^{\circ} \mathrm{C}$ ); ${ }^{* * *}$ - significance of correlation at $\mathrm{p}<0.0001$ according to student statistic.
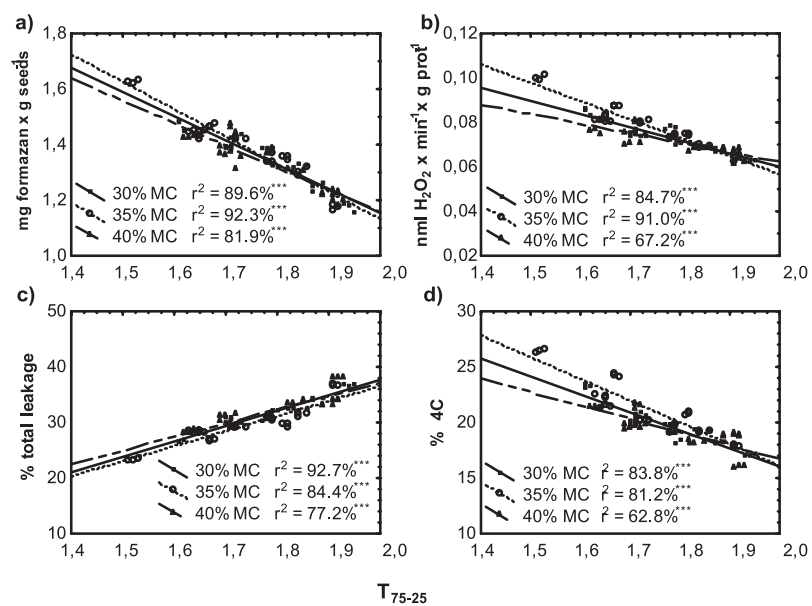

Fig. 6. Linear regressions between mean germination time (MGT) and physiological activities - a) total activity of dehydrogenases - TAD, $b$ ) activity of catalase $-A C$, c) leakage of electrolytes - LE, and d) activity of cell cycle - ACC - of tomato seeds imbibed by soaking in an excessive amount of water (M1), soaking in a limited amount of water (M2), or matriconditioning (M3), and then incubated for one, 10, and 12 days in relation to applied moisture content $(\mathrm{MC})(30.0,35.0$ and $40.0 \%) ;{ }^{* * *}$ - significance of correlation at $\mathrm{p}<0.0001$ according to student statistic. to 1.52 days (M1), 1.67 days (M2), and 1.82 days (M3), whereas for the control it was 2.26 days. Based on these parameters (MGT and $\mathrm{T}_{75-25}$ ), it is possible to establish the optimal conditions for seed priming, as was confirmed by our earlier studies [12-13]. These two parameters indicated that hydration up to a moisture content of $35.0 \%$ and subsequent incubation for 10 days were the most favorable for priming tomato seeds.

We evaluated the length of the main shoot at the stage of flowering plants. The length of main shoots of plants derived from the conditioned seeds ranged from 49.4-71.9 $\mathrm{cm}$, and it was higher than in control, in degrees depending on the used method (Table 2). The average number of inflorescences of plants derived from the conditioned seeds was also higher as compared to the control (1.5). The highest number of inflorescences was observed in plants grown from seeds soaked in an excessive amount of water (M1; Table 2). This indicates that because plant development depends on seed quality, the studied physiological markers can also indicate the growth of crops.

The presented research shows that the studied physiological events can be useful markers indicating not only seed germinability, but also can be helpful in controlling priming technology. The activity of catalase (AC) increased with the duration of priming [7, 9]. The higher activity of catalase in seeds is supposed to be connected with the reinforcement of the defense against stress caused by free radicals $[6,20]$. In the presented experiment, the quantity of $\mathrm{AC}$ in the control seeds was at a level of $0.063 \mathrm{nmol} \mathrm{H}_{2} \mathrm{O}_{2} \times \mathrm{min}^{-1} \mathrm{x} \mathrm{g} \operatorname{prot}^{-1}$ (Table 3). The activity of this enzyme in the primed seeds increased up to 0.071-0.099 (M1), 0.068-0.087 (M2), and 0.0640.074 (M3) nmol $\mathrm{H}_{2} \mathrm{O}_{2} \times \min ^{1} \mathrm{x} \mathrm{g} \mathrm{prot}^{-1}$. A different level of these enzyme activities was highly correlated with seed biological quality [18]. The presented research proves that priming increased catalase activity in seeds and indicated a high correlation between $\mathrm{AC}$ and the germinability parameters of primed tomato seeds. Thus, this enzyme can be considered the possible marker of primed seeds.

In turn, increased total activity of dehydrogenases (TAD) can be connected with higher intensity of the processes of seed respiration in the course of incubation. Dehydrogenase is a respiratory enzyme whose activity proves that the cell is alive. Our results for tomato, like those of [21] for onion seeds, show higher TAD in the conditioned seeds in comparison with the untreated ones. In our study, the TAD in the control seeds was determined to be $0.76 \mathrm{mg}$ formazan $\mathrm{x}$ g seeds ${ }^{-1}$. Depending on the method of seed conditioning, TAD increased up to 1.351.63 (M1), 1.31-1.47 (M2), and 1.17-1.35 (M3) mg formazan $\mathrm{x} \mathrm{g} \mathrm{seeds} \mathrm{g}^{-1}$ (Table 3 ). These data indicate that priming increases the activity of respiratory enzymes in seeds. In addition, the presented results show a high correlation between the germination parameters and TAD, and thus they can be recommended as useful markers for primed tomato seed quality.

A significant improvement in the integrity of cell membranes was noticed in the conditioned tomato seeds, 
Table 1. Mean germination time (MGT) and time between 25 and $75 \%$ of germination $\left(\mathrm{T}_{75-25}\right)$ at $15^{\circ} \mathrm{C}$ of tomato seeds imbibed up to $30.0,35.0$ and $40.0 \% \mathrm{MC}$ by soaking in excessive amount of water (M1), soaking in limited amount of water (M2), or by matriconditioning (M3), and then incubated for 1,10 and 12 days at $20^{\circ} \mathrm{C}$.

\begin{tabular}{|c|c|c|c|c|c|c|}
\hline \multirow{3}{*}{$\begin{array}{c}\text { Moisture Content } \\
{[\%]}\end{array}$} & \multicolumn{3}{|c|}{$\begin{array}{l}\text { Mean germination time } \\
\text { [days] }\end{array}$} & \multicolumn{3}{|c|}{$\begin{array}{c}\text { Time between } 25 \text { and } 75 \% \\
\text { of germination [days] }\end{array}$} \\
\hline & \multicolumn{6}{|c|}{$\begin{array}{l}\text { Incubation time } \\
\text { [days] }\end{array}$} \\
\hline & 1 & 10 & 12 & 1 & 10 & 12 \\
\hline 9.9 (control) & $6.52 \mathrm{a}$ & $6.52 \mathrm{a}$ & $6.52 \mathrm{a}$ & $2.26 \mathrm{a}$ & $2.26 \mathrm{a}$ & $2.26 \mathrm{a}$ \\
\hline \multicolumn{7}{|c|}{ Soaking in excessive amount of water (M1) } \\
\hline 30.0 & 4.231 & $3.26 \mathrm{o}$ & 4.231 & $1.71 \mathrm{i}$ & 1.611 & $1.71 \mathrm{i}$ \\
\hline 35.0 & $3.67 \mathrm{n}$ & $2.53 \mathrm{p}$ & 4.081 & $1.64 \mathrm{k}$ & 1.521 & $1.65 \mathrm{k}$ \\
\hline 40.0 & $4.51 \mathrm{k}$ & 4.141 & $4.53 \mathrm{k}$ & $1.70 \mathrm{i}$ & $1.63 \mathrm{kl}$ & $1.71 \mathrm{i}$ \\
\hline \multicolumn{7}{|c|}{ Soaking in limited amount of water (M2) } \\
\hline 30.0 & $5.32 \mathrm{f}$ & 4.301 & 4.281 & $1.80 \mathrm{gh}$ & $1.72 \mathrm{i}$ & $1.78 \mathrm{~h}$ \\
\hline 35.0 & $4.66 \mathrm{j}$ & $3.29 \mathrm{o}$ & 4.071 & $1.79 \mathrm{~h}$ & $1.67 \mathrm{j}$ & $1.73 \mathrm{i}$ \\
\hline 40.0 & $5.49 \mathrm{e}$ & $3.80 \mathrm{~m}$ & $4.88 \mathrm{~h}$ & $1.83 \mathrm{ef}$ & $1.71 \mathrm{i}$ & $1.79 \mathrm{~h}$ \\
\hline \multicolumn{7}{|c|}{ Matriconditioning (M3) } \\
\hline 30.0 & $6.13 \mathrm{c}$ & $4.76 \mathrm{i}$ & $5.29 \mathrm{f}$ & $1.94 \mathrm{~b}$ & $1.84 \mathrm{e}$ & $1.88 \mathrm{~d}$ \\
\hline 35.0 & $5.95 \mathrm{~d}$ & 4.271 & $4.81 \mathrm{hi}$ & $1.91 \mathrm{c}$ & $1.82 \mathrm{fg}$ & $1.85 \mathrm{e}$ \\
\hline 40.0 & $6.22 \mathrm{~b}$ & $5.25 \mathrm{f}$ & $5.10 \mathrm{~g}$ & $1.92 \mathrm{bc}$ & $1.90 \mathrm{~cd}$ & $1.92 \mathrm{c}$ \\
\hline
\end{tabular}

Means with the same letters are not significantly different at $\mathrm{p}<0.05$ according to Duncan's multiple range test

which was determined by measurements of electrolyte leakage (LE) from embryos. Compared with the LE from the control seeds $(47.0 \%)$, the amount of electrolyte leakage from the primed seeds was reduced significantly to $23.3 \%$ (M1), 26.8\% (M2), and 29.5\% (M3) (Table 3). Our results, like those obtained by [22] and [23], suggest that a rapid LE test (four hours) can help partly predict the results of the germination test, which requires 7-42

Table 2. Growth and development of plants derived from the seed moistened by soaking in excessive amount of water (M1), soaking in limited amount of water (M2), or by matriconditioning (M3) up to $35 \% \mathrm{MC}$ and then incubated for 10 days at $20^{\circ} \mathrm{C}$.

\begin{tabular}{|c|c|c|}
\hline Method of conditioning & $\begin{array}{c}\text { Length of the } \\
\text { main shoot } \\
{[\mathrm{cm}]}\end{array}$ & $\begin{array}{c}\text { Number } \\
\text { of } \\
\text { inflorescences }\end{array}$ \\
\hline Control & $40.6 \mathrm{a}$ & $1.5 \mathrm{a}$ \\
\hline $\begin{array}{c}\text { Soaking in excessive } \\
\text { amount of water (M1) }\end{array}$ & $71.9 \mathrm{~d}$ & $2.3 \mathrm{~b}$ \\
\hline $\begin{array}{c}\text { Soaking in limited amount } \\
\text { of water (M2) }\end{array}$ & $63.5 \mathrm{c}$ & $1.8 \mathrm{a}$ \\
\hline Matriconditioning (M3) & $49.4 \mathrm{~b}$ & $1.6 \mathrm{a}$ \\
\hline
\end{tabular}

Means with the same letters are not significantly different at $\mathrm{p}<0.05$ according to Duncan's multiple range test days, depending on the species. The reduced leakage of electrolytes shows that seed priming may have contributed to limiting oxidation of phospholipids, which are the active compounds of membranes. This is also in line with the findings of [24], which indicate that during the hydration process cell membranes reorganize themselves to attain the original structure, disturbed while drying, or because of the rapid entering of water into cells during the initial period of seed soaking. Significant correlations between the leakage of electrolytes and the physiological or biochemical parameters of seed germination were observed for seeds of many species, e.g., cucumber [25], cauliflower [26], cabbage [27-28], and durum wheat [29]. The high correlations between the values of LE and MGT or $\mathrm{T}_{75-25}$ (also found in our study), suggest that conductivity readings may be used as a routine marker for indicating seed quality.

Synchronized and faster germination of seeds can be attributed to the enhanced synthesis of DNA, RNA, and proteins during priming [30]. Our results show that hydration of tomato seeds during priming was associated with the beginning of DNA replication in the radical cells. DNA replication is linked to the cell cycle, whereby higher or lower activity is often marked by a higher or lower ratio, respectively, of 4C DNA (G2 phase) and 2C DNA (G0/G1 phase) [9]. In our experiment, the priming of seeds by hydration up to $35.0 \% \mathrm{MC}$ and then incubation for 10 days resulted in a beneficial increase in $4 \mathrm{C}$ signals 
Table 3. Total activity of dehydrogenases (TAD), activity of catalase (AC), leakage of electrolytes (LE), and activity of cell cycle (ACC) in tomato seeds imbibed up to 30,35 and $40 \% \mathrm{MC}$ by soaking in excessive amount of water (M1), soaking in limited amount of water (M2), or by matriconditioning (M3), and then incubated for 1,10 and 12 days at $20^{\circ} \mathrm{C}$.

\begin{tabular}{|c|c|c|c|c|c|c|c|c|c|c|c|c|}
\hline \multirow{3}{*}{$\begin{array}{l}\text { Moisture } \\
\text { content } \\
{[\%]}\end{array}$} & \multicolumn{3}{|c|}{ 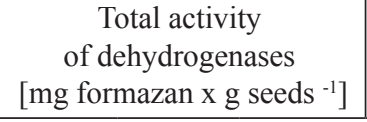 } & \multicolumn{3}{|c|}{$\begin{array}{c}\text { Activity of catalase } \\
{\left[\mathrm{nmol} \mathrm{H}_{2} \mathrm{O}_{2} \times \text { min }^{-1} \times \text { g prot }^{-1}\right]}\end{array}$} & \multicolumn{3}{|c|}{$\begin{array}{c}\text { Leakage of electrolytes } \\
{[\% \text { total leakage }]}\end{array}$} & \multicolumn{3}{|c|}{$\begin{array}{l}\text { Activity of cell cycle } \\
{[\% 4 C]}\end{array}$} \\
\hline & \multicolumn{12}{|c|}{ Incubation time [days] } \\
\hline & 1 & 10 & 12 & 1 & 10 & 12 & 1 & 10 & 12 & 1 & 10 & 12 \\
\hline $\begin{array}{c}9.9 \\
\text { (control) }\end{array}$ & $0.76 \mathrm{~m}$ & $0.76 \mathrm{~m}$ & $0.76 \mathrm{~m}$ & $0.063 \mathrm{k}$ & $0.063 \mathrm{k}$ & $0.063 \mathrm{k}$ & $47.0 \mathrm{a}$ & $47.0 \mathrm{a}$ & $47.0 \mathrm{a}$ & $11.9 \mathrm{p}$ & $11.9 \mathrm{p}$ & $11.9 \mathrm{p}$ \\
\hline \multicolumn{13}{|c|}{ Soaking in excessive amount of water $1: 3 \mathrm{v} / \mathrm{v}$ (M1) } \\
\hline 30.0 & $1.39 \mathrm{f}$ & $1.47 \mathrm{~b}$ & $1.39 \mathrm{f}$ & $0.075 \mathrm{gh}$ & $0.085 \mathrm{bc}$ & $0.076 \mathrm{fg}$ & $30.9 \mathrm{ij}$ & $26.7 \mathrm{o}$ & $29.8 \mathrm{kl}$ & $20.2 \mathrm{~g}$ & $23.3 \mathrm{c}$ & $19.8 \mathrm{hi}$ \\
\hline 35.0 & $1.44 \mathrm{de}$ & $1.63 \mathrm{a}$ & $1.44 \mathrm{~cd}$ & $0.082 \mathrm{~cd}$ & $0.099 \mathrm{a}$ & $0.081 \mathrm{de}$ & $28.2 \mathrm{n}$ & $23.3 \mathrm{p}$ & $28.3 \mathrm{n}$ & $22.3 \mathrm{~d}$ & $26.4 \mathrm{a}$ & $21.4 \mathrm{e}$ \\
\hline 40.0 & $1.35 \mathrm{~g}$ & $1.43 \mathrm{de}$ & $1.37 \mathrm{f}$ & $0.071 \mathrm{ij}$ & $0.076 \mathrm{f}-\mathrm{h}$ & $0.076 \mathrm{f}-\mathrm{h}$ & $31.4 \mathrm{~h}$ & $28.4 \mathrm{n}$ & $30.2 \mathrm{k}$ & $19.5 \mathrm{ij}$ & $21.3 \mathrm{e}$ & $19.8 \mathrm{hi}$ \\
\hline & \multicolumn{12}{|c|}{ Soaking in limited amount of water (M2) } \\
\hline 30.0 & $1.32 \mathrm{hi}$ & $1.43 \mathrm{de}$ & $1.39 \mathrm{f}$ & $0.071 \mathrm{ij}$ & $0.074 \mathrm{gh}$ & 0.078 ef & $32.3 \mathrm{~g}$ & 29.61 & $30.6 \mathrm{j}$ & 18.21 & $20.8 \mathrm{f}$ & $19.8 \mathrm{hi}$ \\
\hline 35.0 & $1.35 \mathrm{~g}$ & $1.47 \mathrm{~b}$ & $1.42 \mathrm{e}$ & $0.074 \mathrm{gh}$ & $0.087 \mathrm{~b}$ & $0.080 \mathrm{de}$ & $30.6 \mathrm{j}$ & $26.8 \mathrm{o}$ & $29.1 \mathrm{~m}$ & $19.6 \mathrm{ij}$ & $24.3 \mathrm{~b}$ & $20.2 \mathrm{gh}$ \\
\hline 40.0 & $1.31 \mathrm{hi}$ & $1.46 \mathrm{bc}$ & $1.38 \mathrm{f}$ & $0.068 \mathrm{j}$ & $0.080 \mathrm{de}$ & $0.073 \mathrm{hi}$ & $33.6 \mathrm{e}$ & $\begin{array}{l}29.2 \\
\mathrm{~lm}\end{array}$ & $31.2 \mathrm{hi}$ & 18.31 & $21.5 \mathrm{e}$ & $19.1 \mathrm{kl}$ \\
\hline \multicolumn{13}{|c|}{ Matriconditioning (M3) } \\
\hline 30.0 & 1.171 & $1.32 \mathrm{~h}$ & $1.25 \mathrm{j}$ & $0.064 \mathrm{k}$ & $0.069 \mathrm{j}$ & $0.068 \mathrm{j}$ & $36.8 \mathrm{c}$ & $32.4 \mathrm{~g}$ & $34.3 \mathrm{~d}$ & $17.1 \mathrm{n}$ & $19.3 \mathrm{jk}$ & 18.31 \\
\hline 35.0 & 1.171 & $1.35 \mathrm{~g}$ & $1.30 \mathrm{i}$ & $0.065 \mathrm{k}$ & $0.074 \mathrm{gh}$ & $0.069 \mathrm{j}$ & $36.7 \mathrm{c}$ & 29.517 & $31.4 \mathrm{~h}$ & $17.8 \mathrm{~m}$ & $20.8 \mathrm{f}$ & $19.2 \mathrm{j}-1$ \\
\hline 40.0 & 1.191 & $1.22 \mathrm{k}$ & $1.23 \mathrm{jk}$ & $0.064 \mathrm{k}$ & $0.068 \mathrm{j}$ & $0.068 \mathrm{j}$ & $38.2 \mathrm{~b}$ & $33.2 \mathrm{f}$ & $34.1 \mathrm{~d}$ & $16.1 \mathrm{o}$ & $18.9 \mathrm{kl}$ & 18.91 \\
\hline
\end{tabular}

Means with the same letters are not significantly different at $\mathrm{p}<0.05$ according to Duncan's multiple range test.

from $11.9 \%$ (control) up to $26.4 \%$ (M1), $24.3 \%$ (M2), and 20.8 (M3; Table 3). We found a positive correlation between the induction of DNA replication, measured as the increase in the presence of $4 \mathrm{C}$ cell nuclei, and the efficiency of the priming treatment of tomato seeds. The presented results, similar to those of [3] and [31], suggest that the cell cycle activity in seed somatic cells could be a cellular marker for detecting both seed maturity and progression of germination during seed priming.

Our present study found significant $(\mathrm{p}<0.001)$ correlations - both positive and negative - between MGT and $\mathrm{T}_{75-25}$ on the one hand, and variables characterizing the physiological state of the processes associated with seed germination on the other. The correlations for MGT and $\mathrm{T}_{75-25}$ determined by linear regression analyses can also be used to assess the sowing value of tomato seeds. It can be inferred that the analyses of the studied physiological changes in seeds caused by priming may be used as useful and rapid markers of seed-sowing quality. In this study, these markers have proven themselves useful at all levels of seed germination subjected to different conditioning methods. The obtained physiological status of primed seeds of the Janosik tomato can constitute a basis for evaluating the progress in seed germination in other varieties of tomato or in seeds of other species of plants. Our results show that despite the numerous data presented in the literature, it is still essential to increase the knowledge concerning rapid detection and signalling changes in seed germinability by means of physiological markers, and optimizing the priming technique. This potential advantage may allow the test to be widely used in many laboratories because of its environmental friendliness.

\section{Conclusions}

The presented study showed positive effects of environment-friendly conditioning methods (soaking in excessive amounts of water, soaking in limited amounts of water, matriconditioning, and subsequent incubation) on the germination parameters of Janosik (Lycopersicon esculentum Mill.) tomato seeds and the growth and development of plants obtained from these seeds. Each method of seed conditioning significantly shortened MGT and $\mathrm{T}_{75-25}$. The research showed significant $(\mathrm{p}<0.001)$ correlations between MGT and $\mathrm{T}_{75-25}$, and the selected physiological processes determining seed germination (activity of catalase, total activity of dehydrogenase, activity of the cell cycle, and leakage of electrolytes). The high correlations between the studied physiological activities and MGT or $\mathrm{T}_{75-25}$ suggest that they can be recommended as routine markers for indicating seed germination quality. 


\section{Acknowledgements}

The authors wish to thank Prof. dr. Elwira Śliwińska for her substantial help in evaluating activity of the cell cycle.

\section{References}

1. DE CASTRO R.D., ZHENG X.Y., BERGERVOET J.H.W., DE VOS C.H.R., BINO R.J. B Tubulin accumulation and DNA replication in imbibing tomato seeds. Plant Physiol. 109, 499, 1995.

2. BRITO C.D., LOUREIRO M.B., TELES C.A.S., SCHUCK M.R., FERNANDEZ L.G., CASTRO R.D. Behavior of Jatropha curcas L. seeds under osmotic stress: germination and cell cycle activity. Acta Sci-Agron. 37 (3), 279, 2015

3. ŚLIWIŃSKA E. Nuclear DNA replication and seed quality. Seed Sci. Res. 19, 15, 2009.

4. GALLARDO K., JOB C., GROOT S.P.C., PUYPE M., DEMOL H., VANDEKERCKHOVE J., JOB D. Proteomic analysis of Arabidopsis seed germination and priming. Plant Physiol. 126, 835, 2001.

5. BEWLEY J.D., BLACK M. Seeds. Physiology of development and germination. $2^{\text {nd }}$ Ed. New York, Plenum Press. 1994.

6. ZHANG F., YU J., JOHNSTON C.R., WANG Y., ZHU K., LU F., ZHANG F., ZOU J. Seed priming with polyethylene glycol induces physiological changes in sorghum (Sorghum bicolor L. Moench) seedlings under suboptimal soil moisture environments. PLoS ONE 10.10, e0140620, 2015.

7. AFZAL I.F., MUNIR C.M., AYUB S.M.A., BASRA A., HAMEED A., NAWAZ A. Changes in antioxidant enzymes, germination capacity and vigour of tomato seeds in response of priming with polyamines. Seed Sci. Technol. 37, 765, 2009.

8. VARIER A., VARI A.K., DADLANI M. The sub-cellular basis of seed priming. Current Science. 99, 450, 2010.

9. CHEN K., ARORA R. Priming memory invokes seed stresstolerance. Environ. Exp. Bot. 94, 33, 2013.

10. MCDONALD M.B. Seed Technology and its Biological Basis. In: Black M., Bewley J.D. (eds.): Sheffield Academic Press. England; CRC Press. U.S.A. and Canada. 287, 2000.

11. TAYLOR A., HALMER P. Seed physiology: advances and technology innovations. Fisiologia de Sementes. 20, 72, 2010.

12. BADEK B., VAN DUIJN B., GRZESIK M. Effects of water supply methods and seed moisture content on germination of China aster (Callistephus chinensis) and tomato (Lycopersicon esculentum Mill.) seeds. Eur. J. Agron. 24, 45, 2006.

13. BADEK B., VAN DUIJN B., GRZESIK M. Effects of water supply methods and incubation on germination of China aster (Callistephus chinensis) seeds. Seed Sci. Technol. 35, 569, 2007.

14. ISTA. International Rules for Seed Testing. Seed Sci. Technol. 2011

15. GÓRNIK K., GRZESIK M. Effect of Asahi SL on China aster 'Aleksandra' seed yield, germination and some metabolic events. Acta Physiol. Plant. 24, 379, 2002.

16. BAILLY C., BENAMAR A., CORBINEAU F., CÔME D. Changes in malondialdehyde content and in superoxide dismutase, catalase and glutathione reductase activities in sunflower seeds as related to deterioration during accelerated ageing. Physiol. Plantarum. 97, 104, 1996.

17. SLIWINSSKA E. Zastosowanie cytometrii przepływowej do oznaczania zawartości DNA u roślin. Estimation of DNA content in plants using flow cytometry. Postępy Biologii Komórki, 24, 165, 2008.

18. VENTURA L., DONÀ M., MACOVEI A., CARBONERA D., BUTTAFAVA A., MONDONI A., ROSSI G., BALESTRAZZI A. Understanding the molecular pathways associated with seed vigor. Plant Physiol. Bioch. 60, 196, 2012.

19. GRZESIK M., ROMANOWSKA-DUDA Z.B. Biotechnological potential of algae and Cyanobacteria in improving germination, growth and metabolic activity of corn plants by grain conditioning and root application. Pol. J. Environ. Stud. 23, 1147, 2014.

20. DEL RYO L.A., CORPAS F.J., SANDALIO L.M., PALMA J.M., GO'MEZ M., BARROSO J.B. Reactive oxygen species, antioxidant systems and nitric oxide in peroxisomes. J. Exp. Bot. 53, 1255, 2002.

21. KĘPCZYŃSKA E., PIĘKNA-GROCHALA J., KĘPCZYŃSKI J. Effect of matriconditioning on onion seed germination, seedling emergence and associated physical and metabolic events. Plant Growth Regul. 41, 269, 2003.

22. MATTHEWS S., POWELL A.A. Electrical conductivity vigour test: physiological basis and use. ISTA News Bulletin. 131, 32, 2006.

23. DEMIR I., CEBECI C., GULOKSUZ T. Electrical conductivity measurement to predict germination of commercially available radish seed lots. Seed Sci. Technol. 40, 229, 2012.

24. AMOOAGHAIE R., NIKZAD K., SHAREGHI B. The effect of priming on emergence and biochemical changes of tomato seeds under suboptimal temperatures. Seed Sci. Technol. 38, 508, 2010.

25. KERE G.M., Guo Q., Chen J. Growth and physiological responses of cucumber (Cucumis sativus L.) to sodium chloride stress under solid hydroponics J. Environ. Agric. Sci. 6, 47, 2016.

26. MIRDAD Z., POWELLA.A., MATTHEWS S. Prediction of germination in artificially aged seeds of Brassica spp. using the bulk conductivity test. Seed Sci Technol 34, 273, 2006.

27. DEMIR I., MAVI K., KENANOGLU B.B., MATTHEWS S. Prediction of germination and vigour in naturally aged commercially available seed lots of cabbage (Brassica oleracea var. capitata) using the bulk conductivity method. Seed Sci Technol 36, 509, 2008.

28. MATTHEWS S., DEMIR I., CELIKKOL T., KENANOGLU B.B., MAVI K. Vigour tests for cabbage seeds using electrical conductivity and controlled deterioration to estimate relative emergence in transplant modules. Seed Sci Technol 37, 736, 2009.

29. BAJJI M., KINET J.M., LUTTS S. The use of the electrolyte leakage method for assessing cell membrane stability as a water stress tolerance test in durum wheat. Plant Growth Regul. 36.1, 61, 2002.

30. BRAY C.M., DAVISON P.A., ASHRAF M., TAYLOR R.M. Biochemical changes during priming of leek seeds. Ann Bot. 63, 185, 1989.

31. ONWIMOL D., CHANPRAME S., THONGKET T. Arrest of cell cycle associated with delayed radicle emergence in deteriorated cucumber seed. Seed Sci. Technol. 40, 238, 2012. 